\title{
Characterisation of a fimbrial, mannose-resistant and eluting haemagglutinin (MREHA) produced by strains of Salmonella of serotype Sendai
}

\author{
D. C. OLD, D. E. YAKUBU and B. W. SENIOR \\ Department of Medical Microbiology, University of Dundee Medical School, Ninewells Hospital, Dundee DD1 \\ 9SY
}

\begin{abstract}
Summary. Strains of Salmonella of serotype Sendai, producing a mannose-resistant and eluting haemagglutinin (MREHA) when cultured at $37^{\circ} \mathrm{C}$ but not at $18^{\circ} \mathrm{C}$, were examined by electronmicroscopy after negative staining. Production of this MREHA, previously thought to be nonfimbrial, was correlated with the presence of thick fimbriae with an external diameter of $13.6 \mathrm{~nm}$. These fimbriae were readily fragmented and, when purified, had an estimated $M_{r}$ of $28 \mathrm{Kda}$. Production of fimbrial MREHA by Sendai strains was associated with the ability to adhere to a wide range of substrates and to form a fimbrial pellicle at the surface of liquid media incubated statically in air. The origin of this unusual Sendai fimbrial MREHA is unknown. Thin filamentous structures produced independently of fimbrial MREHA by Sendai strains were also described. Fimbrial MREHA was not produced by strains of the antigenically similar serotype Miami which, however, and unlike Sendai strains, formed mannose-sensitive haemagglutinin and type-1 fimbriae. The ability to differentiate strains of Miami and Sendai (serotype 1,9,12:a:1,5) by means of their fimbriae is noted.
\end{abstract}

\section{Introduction}

Most strains ( $80 \%$ ) of Salmonella possess type-1 fimbriae (Duguid et al., 1966; Duguid and Old, 1980 ; Duguid, 1985) which are polymers of fimbrillin, a protein of $21 \mathrm{Kda}$ with a high proportion $(40 \%)$ of hydrophobic amino acids (Korhonen et al., 1980). Type-1 fimbriae of salmonellae of different serotypes are antigenically diverse, share a major fimbrial antigen and carry a common adhesin which recognises mannosyl-containing residues (Duguid et al., 1966; Duguid and Campbell, 1969, Old, 1972; Duguid, 1985). The adhesive properties of type-1 fimbriate salmonellae can be inhibited by $D$-mannose, its analogues and a few, highly specific oligosaccharides (Duguid et al., 1966; Old, 1972; Firon et al., 1983). Receptors for type-1 fimbriae are distributed in a wide range of cells including erythrocytes of many animal species, and detection of mannose-sensitive haemagglutinating activity (MSHA) in salmonella cultures affords good presumptive evidence of type-1 fimbriation (Duguid et al., 1966; Old, 1985).

Other kinds of haemagglutinating activity not

Received 10 March 1989; accepted 20 March 1989. inhibited by $\mathrm{D}$-mannose have also been described in salmonellae. Some of these mannose-resistant haemagglutinating activities (MRHAs) are associated with fimbriae, others with non-fimbrial material (Duguid and Old, 1980; Old, 1985). Thus, rare strains of Salmonella of subspecies 1-3 possess thin fimbriae (of external diameter $\leqslant 4 \mathrm{~nm}$ ) which render cultures inagglutinable in all available $\mathrm{O}$ antisera (Rohde et al., 1975; Aleksić et al., 1978). The thin fimbriae of subspecies-1 salmonellae are serologically related to the type-3 fimbriae of strains of Enterobacter, Klebsiella and Yersinia (Old and Adegbola, 1985) and, like them, are associated with a mannose-resistant and klebsiella-like haemagglutinin (MR/K-HA, see Duguid and Old, 1980) which agglutinates tannic acid-treated red-blood cells (Adegbola et al., 1983). The thin fimbriae of salmonellae of subspecies 2 and 3 are also associated with a "tanned red-cell" haemagglutinin (Adegbola et al., 1983; Old, 1985) but they are serologically unrelated to the type-3 fimbriae of other Enterobacteriaceae (Old and Adegbola, 1985).

Non-fimbrial MRHAs are produced by salmonellae of many different serotypes, mostly from subspecies 1 (Jones and Richardson, 1981; Tavendale et al., 1983; Manning et al., 1986; Old and 
Tavendale, 1986; Halula and Stocker, 1987). It is generaily agreed that many of these non-fimbrial MRHAs are diffusible materials not associated with the bacterial cells (Tavendale et al., 1983; Halula and Stocker, 1987), but there is little agreement about their importance in the attachment of salmonellae to mammalian cells (Jones and Richardson, 1981; Tavendale et al., 1983; Manning et al., 1986; Old and Tavendale, 1986) possibly because different kinds of MRHA are involved.

The MRHA produced by strains of Salmonella of serotype Sendai is readily distinguished from other salmonella MRHAs because it has the unusual property of "elution", i.e., adherent bacteria elute from the red cells as the temperature of the agglutinated mixture is increased (Duguid et al., 1966). "Elution" is a property characteristic of the mannose-resistant and eluting (MRE) HAs found in c. $60 \%$ of strains of Escherichia coli (Duguid et al., 1955, 1979) and, more rarely, with HAs of a few other species, e.g., Haemophilus influenzae (Scott and Old, 1981) and Yersinia frederiksenii (Old et al., 1985). In this paper the characters of the Sendai MREHA, originally thought to be non-fimbrial (Duguid et al., 1966), are described.

\section{Materials and methods}

\section{Bacteria}

Seven strains of $S$. enterica subsp. enterica (see Le Minor and Popoff, 1987) with the antigenic formula 1,9,12:a: 1,5 were examined: three strains (NCTC 5772, 71.K and CNS 3666.51 [Hanoi]) were received as serotype Sendai and four strains (187.K, CNS 2.84, CNS 7.84 and CNS 1.85) as serotype Miami. Strain NCTC 5772 was obtained from the National Collection of Type Cultures, Colindale Avenue, London; the other six strains were kindly donated by Professor L. Le Minor, Service des Entérobactéries, Institut Pasteur, Paris, France.

\section{Culture methods}

Tryptone Soya Agar (CM 131) was from Oxoid. Otherwise, the media and methods of culture used were essentially as described before (Duguid et al., 1979; Old et al., 1987). Thus, in tests for the production of haemagglutinins, bacteria were grown serially for $48-\mathrm{h}$ periods in static phosphate-buffered broth ( $\mathrm{pH} 7 \cdot 0, \mathrm{PBB})$ or for $24 \mathrm{~h}$ on phosphate-buffered agar ( $\mathrm{pH} \mathrm{7.0,} \mathrm{PBA)} \mathrm{at}$ $18^{\circ} \mathrm{C}$ or $37^{\circ} \mathrm{C}$. For the isolation of fimbriae from strains NCTC 5772 and 3666.51 , bacteria were grown for $24 \mathrm{~h}$ at $37^{\circ} \mathrm{C}$ on PBA $(500 \mathrm{ml})$ in glass-bottomed bioassay plates $\left(25 \mathrm{~cm}^{2}\right.$, Mast Laboratories). Manipulation of Sendai cultures was performed in appropriate conditions of containment in a category 3 laboratory.

\section{Haemagglutination tests}

Bacteria were harvested and tested for their haemagglutination titres as before (Adegbola and Old, 1982). MREHA titres were expressed as the haemagglutinating power (HP) estimated in tests with the most sensitive species of red-blood cell and MSHA titres similarly in tests with guinea-pig cells (Old, 1985).

\section{Improved salt-aggregation test}

Different concentrations of ammonium sulphate $(0 \cdot 02-$ $4.0 \mathrm{M}$ ) were prepared in $0.02 \mathrm{M}$ sodium-phosphate buffer (pH 6.8) containing methylene blue. Equal volumes of bacterial suspension $\left(c .5 \times 10^{9} \mathrm{cells} / \mathrm{ml}\right)$ and solutions of ammonium sulphate at different concentrations were mixed with tooth picks on hydrophobic paper (Rozgonyi et al., 1985). The concentration of ammonium sulphate at which bacteriàl aggregation occurred was scored immediately after mixing and confirmed next day by examination of the dried-up mixtures.

\section{HEp 2 cell-adhesion tests}

HEp 2 cells obtained from Flow Laboratories (Irvine, Scotland) were maintained according to the procedures detailed by Tavendale et al. (1983).

Bacterial cultures, grown in PBB or on PBA at $18^{\circ} \mathrm{C}$ or $37^{\circ} \mathrm{C}$, were diluted in Eagle's Minimal Essential Medium (Gibco Europe Ltd, Paisley, Scotland) supplemented with fetal bovine serum $0.5 \% \mathrm{v} / \mathrm{v}, 20 \mathrm{mM}$ glutamine and HEPES buffer (pH 7.3) (Gibco) $2 \% \mathrm{v} / \mathrm{v},\left(1 \times 10^{9}\right.$ bacteria/ $\mathrm{ml})$. Static overlay tests performed in the absence or presence of $\propto$-methyl-D-mannoside $(\alpha \mathrm{MM}) 0 \cdot 2 \% \mathrm{w} / \mathrm{v}$ were incubated for $1 \mathrm{~h}$; washing and staining procedures followed the methods of Tavendale et al. (1983). The numbers of bacteria attached per epithelial cell and the percentages of epithelial cells showing adherent bacteria were estimated from counts of $c .200$ cells.

\section{Other adhesion tests}

Preparation of, and adherence to, other mammalian cell types followed previously published methods: human buccal epithelial cells (Burke and Axon, 1987); mouse duodenal epithelial cells (Sato and Okinaga, 1987); and mouse enterocytes (Lindquist et al., 1987).

\section{Electronmicroscopy}

PBB- or PBA-grown bacteria suspended in water were placed on clean dental-wax sheets (EMscope Laboratories Ltd, Ashford, Kent). A copper grid (3.05 mm diameter), coated with formvar and carbon, was placed on, and allowed to remain in contact with, the culture drop for $c$. $20 \mathrm{~min}$. Bacteria were washed through 2 or 3 drops of glass-distilled water and stained for $1 \mathrm{~min}$ with uranyl acetate $(\mathrm{pH} 4.0) 0.3 \% \mathrm{w} / \mathrm{v}$, ammonium molybdate $(\mathrm{pH}$ $7 \cdot 0) 2 \% \mathrm{w} / \mathrm{v}$ or phosphotungstic acid $(\mathrm{pH} 6.8) 0.3 \% \mathrm{w} / \mathrm{v}$. 
After removal of excess stain, grids were dried and each side of the grid was exposed to ultraviolet light for $2 \mathrm{~min}$ before examination with a Jeol $100 \mathrm{CX}$ transmission electronmicroscope.

\section{Isolation and purification of fimbriae}

Bacteria from an overnight PBA culture grown on a biossay plate (vide supra) were harvested in nutrient broth $(10 \mathrm{ml})$ and the resultant dense suspension $\left(\geqslant 10^{12}\right.$ bacteria $/ \mathrm{ml})$ was heated $\left(60^{\circ} \mathrm{C}\right.$ for $\left.20 \mathrm{~min}\right)$ to detach fimbriae. Bacteria were deposited by centrifugation ( $3600 \mathrm{~g}$ for $20 \mathrm{~min}$ ) and the fimbriae in the supernate were concentrated either by centrifugation at $150000 \mathrm{~g}$ for $2 \mathrm{~h}$ or by precipitation with saturated ammonium sulphate $50 \% \mathrm{w} / \mathrm{v}$ overnight at $4{ }^{\circ} \mathrm{C}$. After dissolving the deposit in $50 \mathrm{~mm}$ Tris- $\mathrm{HCl}$ buffer ( $\mathrm{pH} 8 \cdot 0$ ) or dialysing the precipitate against this buffer overnight at $4{ }^{\circ} \mathrm{C}$, the material was applied to an anion-exchange Mono $\mathrm{Q}$ column and chromatographed by a fast protein liquid chromatography (FPLC) system (Pharmacia Ltd). Material was eluted from the column with a linear gradient of $0-0.5 \mathrm{M} \mathrm{NaCl}$ and $1 \mathrm{M} \mathrm{NaCl}$ in $50 \mathrm{~mm}$ Tris-HCl buffer ( $\mathrm{pH} \mathrm{8.0)}$. Column fractions were examined by electronmicroscopy and electrophoresis.

\section{Polyacrylamide-gel electrophoresis ( $P A G E$ )}

Column fractions and protein markers of known $\mathbf{M}_{\mathrm{r}}$ (14.4-97.4 Kda) were analysed by sodium dodecyl sulphate (SDS)-discontinuous PAGE after the method of Laemmli (1970). Samples in disruption buffer $(62.5 \mathrm{mM}$ Tris- $\mathrm{HCl}, \mathrm{pH} 6.8$, containing SDS $2 \% \mathrm{w} / \mathrm{v}$, glycerol $10 \%$ $\mathrm{v} / \mathrm{v}, 2$-mercaptoethanol $5 \% \mathrm{v} / \mathrm{v}$, and a trace of bromophenol blue dye) were boiled for $2 \mathrm{~min}$ and applied to slabs of acrylamide $4 \% \mathrm{w} / \mathrm{v}$ in $125 \mathrm{~mm}$ Tris- $\mathrm{HCl}(\mathrm{pH} 6.8)$ containing $\operatorname{SDS} 0.1 \% \mathrm{w} / \mathrm{v}$ over a resolving gel of acrylamide $15 \% \mathrm{w} / \mathrm{v}$ in $375 \mathrm{~mm}$ Tris $-\mathrm{HCl}(\mathrm{pH} 8.8)$ containing $\operatorname{SDS} 0 \cdot 1 \% \mathrm{w} / \mathrm{v}$. Electrophoresis was carried out in the cold at $30 \mathrm{~mA} / \mathrm{gel}$ in $25 \mathrm{mM}$ Tris- $\mathrm{HCl}(\mathrm{pH} 8.3)$ containing $192 \mathrm{~mm}$ glycine and $\operatorname{SDS} 0 \cdot 1 \% \mathrm{w} / \mathrm{v}$ until the dye front reached the bottom of the gel. Gels were stained overnight in Coomassie Brilliant Blue R250 0.1\% w/v in methanol:glacial acetic acid: water $(50: 10: 40)$, destained in several changes of the same solvent and further washed in methanol:acetic acid: water $(10: 10: 80)$. The stained gel was dried under vacuum.

\section{Results}

\section{Haemagglutinins}

When cultured in $\mathrm{PBB}$ or on PBA at $37^{\circ} \mathrm{C}$ for $24 \mathrm{~h}$, two of the Sendai strains (NCTC 5772 and 71.K) produced a haemagglutinin which in the presence of $\alpha \mathrm{MM}$ agglutinated the red blood cells of fowl $(F)$, guinea pig $(G)$, man $(M)$ and ox $(O)$ (i.e., pattern FGMO) but not those of horse, pig and sheep of the seven red cell species routinely used by us. This Sendai MRHA possessed the unusual property of "elution" whereby there was dispersion of the agglutinated red cell-bacteria mixture as the test was warmed from $4^{\circ} \mathrm{C}$ to $45^{\circ} \mathrm{C}$; hence, it was a haemagglutinin of the mannoseresistant and eluting (MRE) kind. Furthermore, Sendai MREHA was not produced by either of these two strains when grown in PBB or on PBA at $18^{\circ} \mathrm{C}$ for 2 days. Sendai strain 3666.51 did not form this MREHA in either of the phosphate-buffered media even after eight serial 2-day subcultures at $18^{\circ} \mathrm{C}$ or $37^{\circ} \mathrm{C}$. None of the three Sendai strains produced MSHA on serial subculture in nutrient broth or PBB at $18^{\circ} \mathrm{C}$ or $37^{\circ} \mathrm{C}$.

When the four strains of serotype Miami were cultured similarly, they produced MSHA in seriallygrown broth cultures at $18^{\circ} \mathrm{C}$ and $37^{\circ} \mathrm{C}$ but none formed MREHA in PBB or on PBA.

\section{Adherence to epithelial cells}

Bacteria from cultures of Sendai strain NCTC 5772 grown in PBB or on PBA at $37^{\circ} \mathrm{C}$ for $24 \mathrm{~h}$ formed moderate amounts of MREHA (titres of 835-875) (table I); when examined in the static overlay test in the absence of $\alpha \mathrm{MM}$, many (48$71 \%$ ) of the HEp2 cells showed adherent bacteria (2-3 bacteria/epithelial cell). The levels of adherence by this strain were similar when tests were made in the presence of $\alpha \mathrm{MM}(52-77 \%$ of the cells showed $3-4 \cdot 2$ bacteria/epithelial cell, table I). Thus, $\alpha \mathrm{MM}$ did not inhibit the adherence of strain NCTC 5772 , as would be expected for a strain that is type1 non-fimbriate and does not form MSHA. Tests with the other two Sendai strains were made, therefore, only in the presence of $\alpha \mathrm{MM}$, i.e., only their MR adherence to HEp2 cells was assessed. $\mathrm{MREHA}^{+}$cultures of strain $71 . \mathrm{K}$ showed the same overall pattern of adherence to HEp2 cells as had strain NCTC 5772, although its adherence was slightly less $(0 \cdot 7-0.9$ bacteria/epithelial cell) than that of strain NCTC 5772 despite the fact that its MREHA titre was greater than that of strain NCTC 5772. Accurate titration of MREHA, however, is difficult (see Old, 1985).

Motility seemed to play no important role in the adherence of bacteria from $\mathrm{MREHA}^{+}$cultures, because poorly motile bacteria from PBA cultures adhered as well as, if not better than, actively motile bacteria from PBB cultures. Neither strain NCTC 5772 nor strain $71 . \mathrm{K}$ was adherent after growth on PBA or in $\mathrm{PBB}$ at $18^{\circ} \mathrm{C}$, i.e., conditions in which they were phenotypically $\mathrm{MREHA}^{-}$and their MREHA titres were 0 (table I). 
Table I. MREHA and adhesion to HEp2 cells by broth- and agar-grown cultures of salmonellae of serotype Sendai

\begin{tabular}{|c|c|c|c|c|c|}
\hline \multirow{2}{*}{$\begin{array}{l}\text { Strain } \\
\text { no. }\end{array}$} & \multirow{2}{*}{$\begin{array}{l}\text { Phosphate- } \\
\text { buffered } \\
\text { medium } \\
(\mathrm{pH} \mathrm{7.0)}\end{array}$} & \multirow{2}{*}{$\begin{array}{l}\text { Temperature of } \\
\text { incubation } \\
\left({ }^{\circ} \mathrm{C}\right)\end{array}$} & \multirow{2}{*}{$\begin{array}{l}\text { MREHA* } \\
\text { titre of } \\
\text { culture }\end{array}$} & \multicolumn{2}{|c|}{$\begin{array}{l}\text { Percentage of HEp2 cells with adherent } \\
\text { bacteria (and average number of attached } \\
\text { bacteria/HEp2 cell) in static overlay tests }\end{array}$} \\
\hline & & & & $-\alpha \mathbf{M M}$ & $+\alpha \mathrm{MM}$ \\
\hline NCTC & Agar & 37 & 875 & $71(2)$ & $77(3)$ \\
\hline \multirow[t]{3}{*}{5772} & Agar & 18 & 0 & $2(<0.1)$ & $2(<0 \cdot 1) \dagger$ \\
\hline & Broth & 37 & 835 & $48(3)$ & $52(4 \cdot 2)$ \\
\hline & Broth & 18 & 0 & $2(<0.1)$ & $2(<0 \cdot 1)$ \\
\hline \multirow[t]{4}{*}{ 71.K } & Agar & 37 & 4040 & NT & $43(0 \cdot 7)$ \\
\hline & Agar & 18 & 0 & NT & $5(<0 \cdot 1)$ \\
\hline & Broth & 37 & 3005 & NT & $52(0.9)$ \\
\hline & Broth & 18 & 0 & NT & $4(<0 \cdot 1)$ \\
\hline \multirow[t]{4}{*}{3666.51} & Agar & 37 & 0 & NT & $3(<0 \cdot 1)$ \\
\hline & Agar & 18 & 0 & NT & 0 \\
\hline & Broth & 37 & 0 & NT & $4(<0 \cdot 1)$ \\
\hline & Broth & 18 & 0 & NT & 0 \\
\hline
\end{tabular}

\footnotetext{
* None of the Sendai strains was type-1 fimbriate; thus, the MSHA titres of their cultures were 0

$\dagger<0 \cdot 1=0-9$ adherent bacteria/ 100 epithelial cells.

NT $=$ not tested.
}

By contrast, bacteria from PBB- and PBA-grown cultures of strain 3666.51 , which did not form MREHA at $18^{\circ} \mathrm{C}$ or $37^{\circ} \mathrm{C}$, adhered poorly (table I). Indeed, bacteria from $37^{\circ} \mathrm{C}$-grown cultures of this strain were as poorly adherent as the phenotypically $\mathrm{MREHA}^{-}$bacteria of the two Sendai strains grown at $18^{\circ} \mathrm{C}$ (table I).

\section{Other adhesive properties}

When the $\mathrm{MREHA}^{+}$strains NCTC 5772 and 71.K were grown statically in air in tubes of $\mathrm{PBB}$ $(10 \mathrm{ml})$ at $37^{\circ} \mathrm{C}, \mathrm{MREHA}$ activity was first detected after $12 \mathrm{~h}$; a pellicle of growth at the broth-air interface first appeared between 18 and $24 \mathrm{~h}$, and was observed in all static PBB cultures incubated for $\geqslant 24 \mathrm{~h}$. The $\mathrm{MREHA}^{-}$strain 3666.51 grown similarly did not form a pellicle. Measurement of the amount of growth (as estimated by turbidity values at $540 \mathrm{~nm}$ ) of cultures of the $\mathrm{MREHA}^{-}$and $\mathrm{MREHA}^{+}$strains showed that the amounts of growth of $\mathrm{MREHA}^{+}$strains incubated for 24-72 h were consistently 1.65-2.35 times greater than those of the MREHA ${ }^{-}$strain grown similarly (data not shown). No such growth advantage for the $\mathrm{MREHA}^{+}$strains was observed in PBB cultures grown at $37^{\circ} \mathrm{C}$ for $<24 \mathrm{~h}$ (i.e., before pellicle formation appeared) or when the strains were cultured in PBB at $18^{\circ} \mathrm{C}$.

Both $\mathrm{MREHA}^{+}$strains also bound to human buccal epithelial cells $(100 \%$ of cells, 33 bacteria/ cell), mouse duodenal epithelial cells ( $95 \%$ of cells, five bacteria/cell) and mouse colonocytes $(94 \%$ of cells, three bacteria/cell) in the presence of $\alpha \mathrm{MM}$. The MREHA $^{-}$strain, tested similarly, showed negligible adherence to these same mammalian cell types (data not shown). Yet both the MREHA ${ }^{+}$ and $\mathrm{MREHA}^{-}$strains were equally hydrophobic, aggregating in $0.02 \mathrm{M}$ ammonium sulphate. Thus, hydrophobicity alone did not account for adherence to epithelial cells.

\section{Fimbriae}

The approximate percentages of fimbriate bacterial cells detected in cultures of the three Sendai strains after growth in phosphate-buffered media at $18^{\circ} \mathrm{C}$ or $37^{\circ} \mathrm{C}$ are shown in table II. Three different kinds of fimbrial (or fibrillar) structures were noted. First, thick fimbriae with an external diameter of $13.6 \mathrm{~nm}$ were present on a high percentage of bacteria in $\mathrm{MREHA}^{+}$cultures of strains NCTC 5772 and $71 . \mathrm{K}$. When these thick fimbriae were attached to the bacterial cells, they appeared long and straight (fig. 1a), but they fragmented readily even in the course of the gentle in-situ washings with water required for electronmicroscopical examination. Thus, most preparations of $\mathrm{MREHA}^{+}$cultures contained large amounts of thick fimbrial fragments detached from the bacterial cells (fig. 1b). The observation that thick fimbriae were more readily observed on 
Table II. Fimbriation of salmonellae of serotype Sendai grown in phosphate-buffered medium

\begin{tabular}{lccccl}
\hline $\begin{array}{l}\text { Strain } \\
\text { no. }\end{array}$ & $\begin{array}{c}\text { MREHA } \\
\text { production }\end{array}$ & $\begin{array}{c}\text { Phosphate- } \\
\text { buffered } \\
\text { medium }\end{array}$ & $\begin{array}{c}\text { Growth } \\
\text { temperature } \\
\left({ }^{\circ} \mathrm{C}\right)\end{array}$ & $\begin{array}{c}\text { Percentage of } \\
\text { fimbriate } \\
\text { bacteria }\end{array}$ & $\begin{array}{c}\text { Kinds of fim- } \\
\text { briae* present }\end{array}$ \\
\hline NCTC & + & Agar & 37 & 63 & Thick and thin \\
5772 & & Agar & 18 & 0 & None \\
& & Broth & 37 & 55 & Thick and thin \\
$71 . \mathrm{K}$ & + & Broth & 18 & 0 & None \\
& & Agar & 37 & 65 & Thick and thin \\
& & Agar & 18 & 0 & None \\
3666.51 & & Broth & 37 & 61 & Thick and thin \\
& & Broth & 18 & 0 & None \\
& & Agar & 37 & 17 & Thin \\
& & Agar & 18 & 0 & None \\
& & Broth & 37 & 16 & Thin \\
& & Broth & 18 & 0 & None \\
\hline
\end{tabular}

* Fimbriae and fibrillar material described are shown in figs. 1-4.

bacteria of Sendai cultures grown in static liquid PBB rather than on solid PBA may have been associated with that lability. Furthermore, the finding that thick fimbriae were readily seen in preparations stained with neutral stains such as ammonium molybdate or phosphotungstate, but not after staining with uranyl acetate $(\mathrm{pH} 4 \cdot 0)$, suggests that the thick fimbriae may also be acidlabile.

In MREHA $^{+}$Sendai cultures, there was a tendency for the cells to aggregate, e.g., as in the formation of fimbrial pellicles (vide supra). Examination of these cultures indicated that the clumping of bacteria was mediated by tangled masses of thick fimbriae which, unlike the straight form shown in fig. $1 a$, had a distinct curly appearance reminiscent of flagellar structures (fig. 2a). However, the flagella

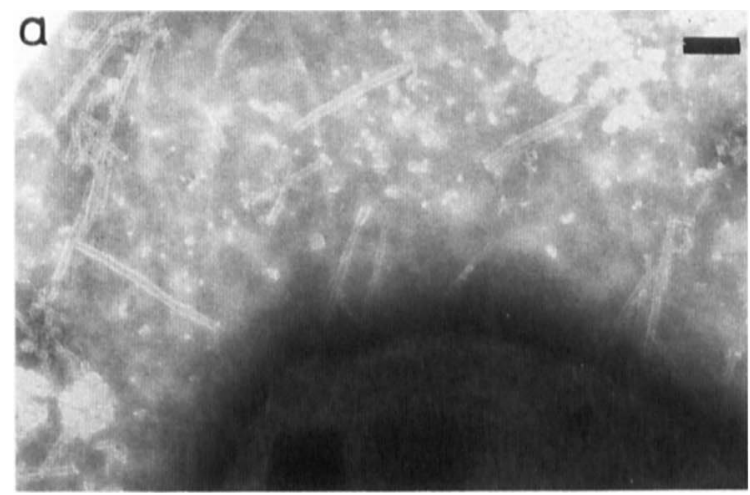

of Sendai strains, like those of other salmonellae (MacNab, 1987), have an external diameter of $c$. $19 \mathrm{~nm}$, i.e., about $50 \%$ thicker than the Sendai thick fimbriae. Furthermore, immuno-electronmicroscopy tests with flagellar antiserum of $\mathrm{Ha}$ specificity (Wellcome Reagents Ltd, Beckenham) showed that Sendai flagella were stained strongly with flagellar antibody whereas the thick curly fimbriae remained uncoated (fig. 2b). Thick fimbriae, straight or curly, were not detected on bacteria from cultures of the $\mathrm{MREHA}^{-}$strain 3666.51 nor from phenotypically $\mathrm{MREHA}^{-}$cultures of the other two Sendai strains grown at $18^{\circ} \mathrm{C}$.

Two other kinds of fimbrial (or fibrillar) structures were observed, each of which was much thinner than the thick $13.6 \mathrm{~nm}$ fimbriae. First, thin fibrillae of $c .3 \mathrm{~nm}$ external diameter were present

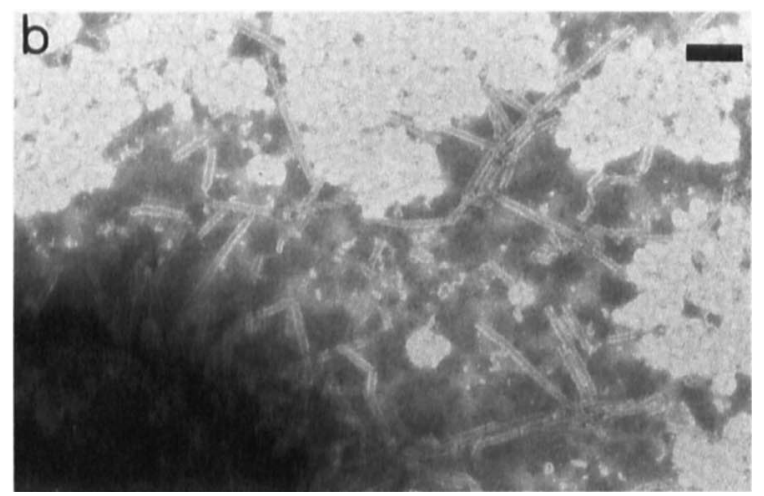

Fig. 1. Ammonium molybdate-stained preparations of $\mathrm{MREHA}^{+}$Sendai strain NCTC 5772 showing thick fimbriae (diameter $13 \cdot 6$ $\mathrm{nm}$ ) : (a) attached to the bacterial cell; (b) fragmented and detached from the bacterial cell. $B a r=100 \mathrm{~nm}$. 

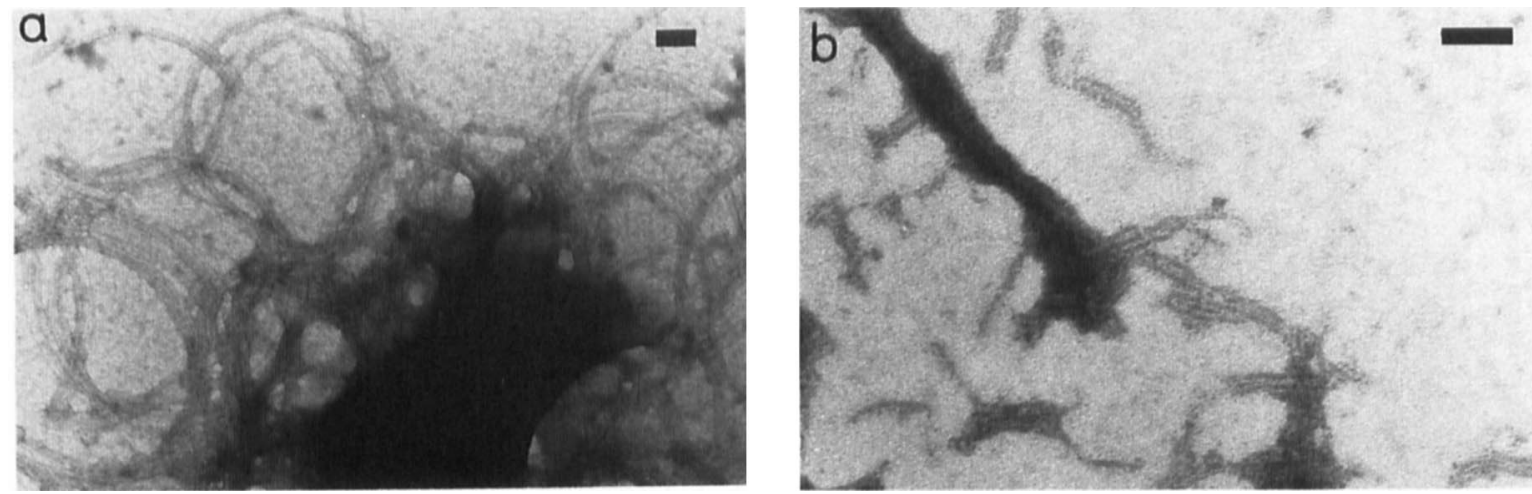

Fig. 2. Ammonium molybdate-stained preparations of $\mathrm{MREHA}^{+}$Sendai strains showing: (a) thick fimbriae of curly appearance on Sendai strain 71.K; (b) antibody-coated flagella and uncoated thick fimbriae of strain NCTC 5772 . Bar $=100 \mathrm{~nm}$.

on bacteria of all three Sendai strains grown at $37^{\circ} \mathrm{C}$, and were more readily seen on bacteria grown in PBB than on PBA (fig. 3). A second kind of fibrillar material with an external diameter of $c$. $2 \mathrm{~nm}$ was found on all three Sendai strains grown at $37^{\circ} \mathrm{C}$; it was detected equally well on bacteria from PBB- and PBA-grown cultures (fig. 4). Although we estimated that c. $16-17 \%$ of the bacteria from $37^{\circ} \mathrm{C}$-grown cultures of Sendai strain 3666.51 possessed one or other, or both, of the thin kinds of fibrillae, we experienced considerable difficulty in seeing these structures and it may be that we have underestimated the actual percentages of bacteria bearing fibrillae. We made no attempt to score the numbers of individual bacteria possessing each of the different kinds of fibrillae and fimbriae.

The $\mathrm{OD}_{280}$ profile of the material eluted from the Mono Q column, after loading with supernate from a heated and centrifuged suspension of Sendai

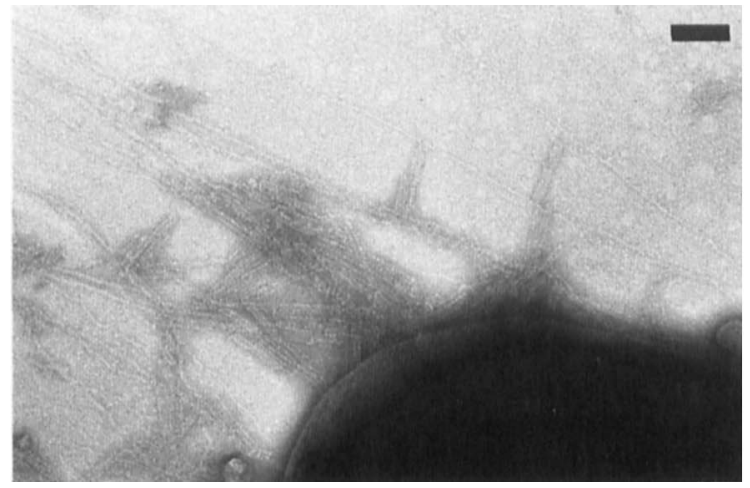

Fig. 3. Ammonium molybdate-stained preparation showing thin fibrillae (diameter c. $3 \mathrm{~nm}$ ) on Sendai strain NCTC 5772. Bar $=100 \mathrm{~nm}$. strain NCTC 5772, is shown in fig. 5. Three major peaks were present at fractions 54,78 and 95 . Samples of fractions $72-80$, eluting at $0.4 \mathrm{M} \mathrm{NaCl}$, were shown by electronmicroscopy to contain thick fimbriae (fig. 6). Furthermore, these thick fimbriae, when detached, gave the same pattern of MRE haemagglutination as the original suspension of MREHA $^{+}$bacteria, suggesting that MREHA was mediated by thick fimbriae. Strain $71 . \mathrm{K}$ behaved similarly. When fractions $72-80$ from Sendai strain NCTC 5772 (or strain 71.K) were pooled and analysed by SDS-PAGE, the subunit $M_{r}$ of the thick fimbriae was estimated as being $c$. $28 \mathrm{Kda}$ (fig. 7). Samples of fractions 54 and 95 from strain NCTC 5772 , eluting at $0.25 \mathrm{M}$ and $1 \mathrm{M} \mathrm{NaCl}$, respectively, were found by electronmicroscopy to contain fibrillar material. Fig. 8a shows fibrillae from fraction 95; sometimes, however, as with material from fraction 54, the filaments were stacked together in sheets (fig. 8b).

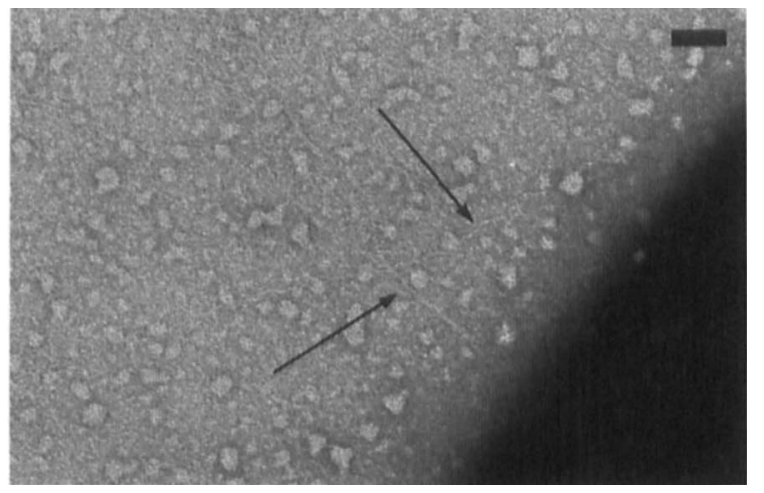

Fig. 4. Phosphotungstic acid-stained preparation showing thin fibrillae (diameter c. $2 \mathrm{~nm}$ ) (arrows) on Sendai strain 71.K. Bar $=100 \mathrm{~nm}$. 


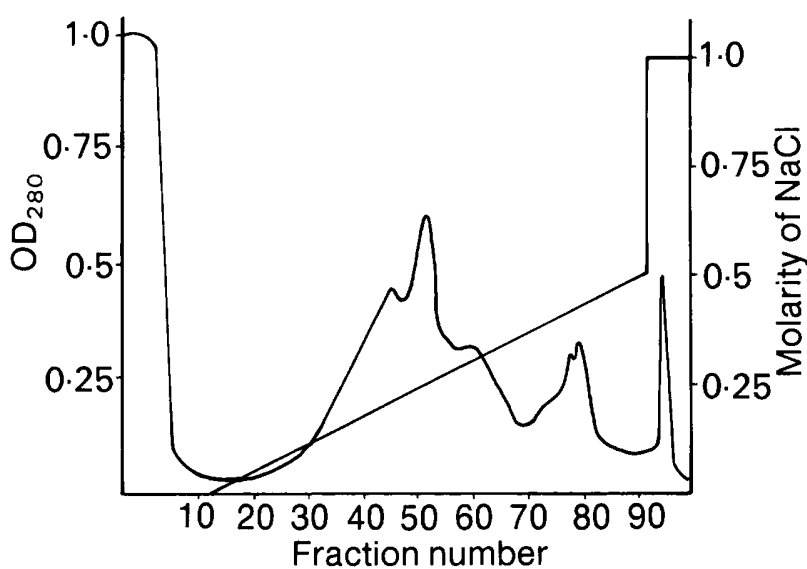

Fig. 5. $\mathrm{OD}_{280}$ profile of material eluted with salt from the Mono $\mathrm{Q}$ column loaded with fimbriae-rich material from MREHA ${ }^{+}$ Sendai strain NCTC 5772.

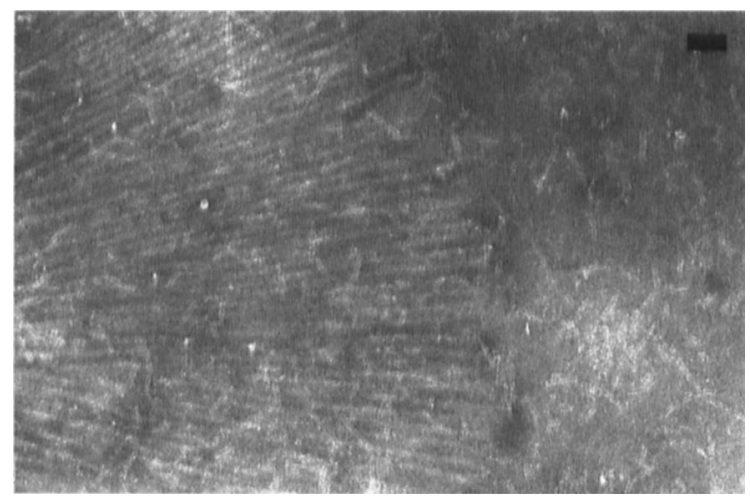

Fig. 6. Ammonium molybdate-stained preparation of material from column fractions containing thick fimbriae from $\mathrm{MREHA}^{+}$Sendai strain NCTC 5772. Bar $=100 \mathrm{~nm}$.

The major difference in the $\mathrm{OD}_{280}$ profile of material from the $\mathrm{MREHA}^{-}$strain 3666.51 , treated and fractionated similarly, was the absence of the major peak corresponding to that of the thick fimbriae (data not shown). Because strain 3666.51 did not produce thick fimbriae, we tried to characterise the thin fimbrial type(s) from that strain. We have been unable, however, to obtain by SDS-PAGE analysis bands whereby the $M_{r}$ of the thin fimbrial type(s) could be assessed.

\section{Discussion}

Considerable advances in the techniques of electronmicroscopy prompted us to seek an explanation of the "non-fimbrial" MREHAs of Salmonella (Duguid et al., 1966) and we have recently established that Salinatis MREHA, agglutinating the red cells of fowl, guinea pig, mouse and ox

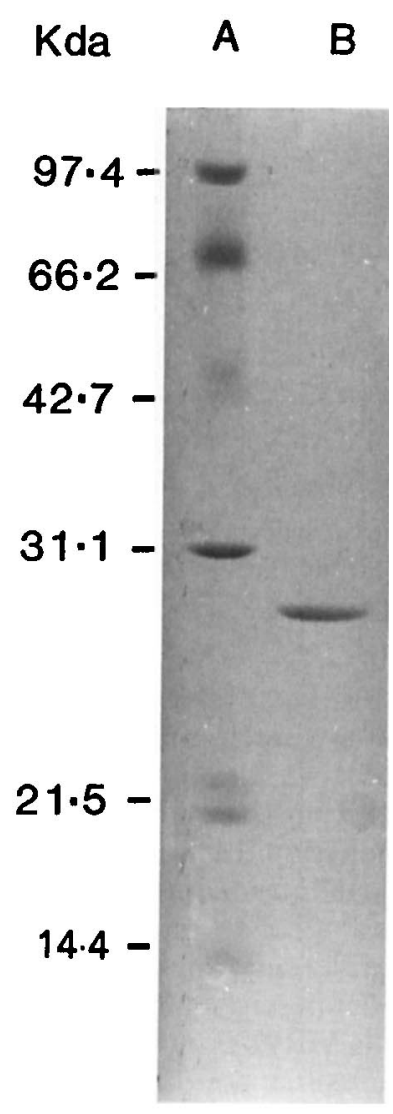

Fig. 7. Coomassie Blue-stained SDS-polyacrylamide gel of thick fimbriae of MREHA ${ }^{+}$Sendai strain NCTC 5772 (lane B). The $\mathrm{Mr}$ values (Kda) of protein markers (lane A) are indicated.

(Duguid et al., 1966), is associated with thin fimbriae which have an external diameter of $3.6 \mathrm{~nm}$ and a subunit $\mathrm{M}_{\mathrm{r}}$ of $19 \mathrm{Kda}$ (Yakubu et al., 1989). In the present study, by contrast, we have shown that Sendai MREHA, agglutinating the red cells of fowl, guinea-pig, man, monkey, ox and rabbit (Duguid et al., 1966), is associated with thick fimbriae which have an external diameter of $13.6 \mathrm{~nm}$ and a subunit $\mathrm{M}_{\mathrm{r}}$ of $28 \mathrm{Kda}$. Furthermore, thick fimbriae in Sendai are extremely fragile, readily fragmented and the associated Sendai MREHA, unlike that of Salinatis (Yakubu et al., 1989), is destroyed by formaldehyde (Duguid et al., 1966). Formaldehyde sensitivity and mechanical fragility were the likely reasons why the thick Sendai fimbriae were not visualised in earlier studies in which formaldehyde-killed cultures were washed twice by centrifugation in distilled water before examination by electronmicroscopy; again, any short stumps of thick fimbriae remaining after these aggressive preparative techniques, would 

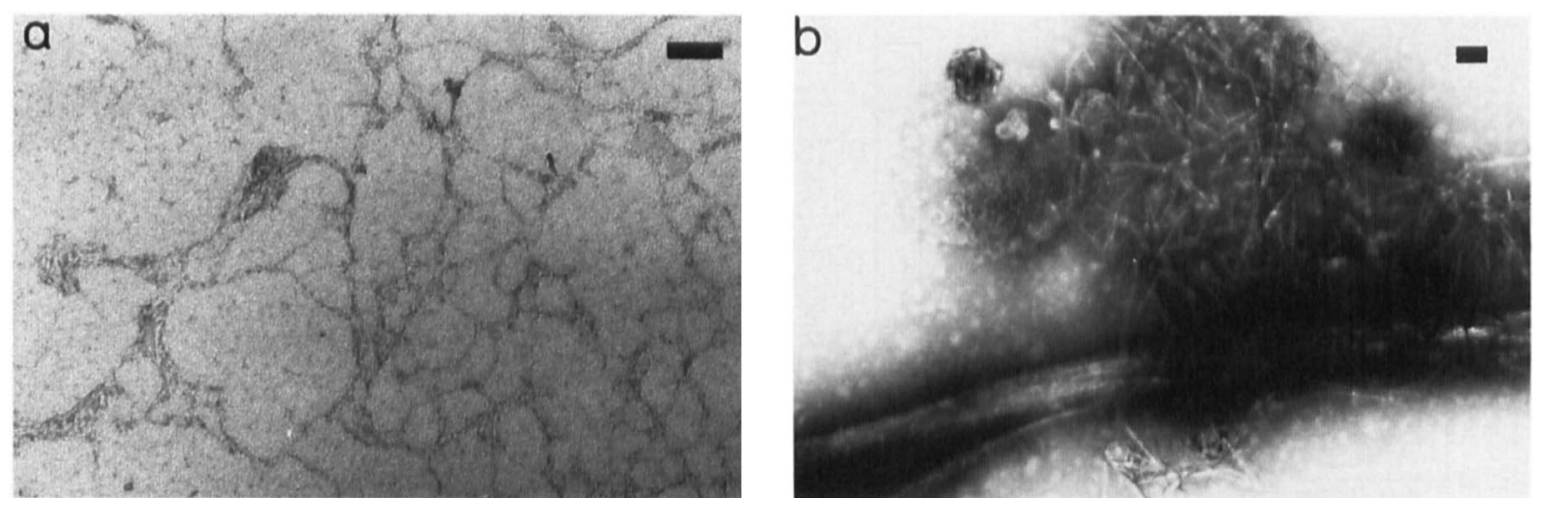

Fig. 8. Ammonium molybdate-stained preparations of fractionated materials from Sendai strains showing material of $c$. 2-nm diameter (a) and c. 3-nm diameter (b), with the latter forming sheets. Bar $=100 \mathrm{~nm}$.

have been difficult to detect by the relatively insensitive shadowing techniques then used $(\mathrm{Du}-$ guid et al., 1966).

It was interesting that the unusual property of MREHA production by salmonellae should be found in two such infrequently occurring salmonellae as Salinatis and Sendai and that their MREHAs should be so different. These fimbrial MREHAs can be readily distinguished by several criteria from other salmonella MRHAs including both the widely distributed, diffusible, non-fimbrial MRHAs (Tavendale et al., 1983; Halula and Stocker, 1987) and the less common type-3 fimbrial MRHAs (Adegbola et al., 1983). Although a relationship between Salinatis and Sendai MREHAs and some of the many MREHAs found in human strains of $E$. coli might seem likely, none of the 10 important classes of fimbrial and "non-fimbrial" MREHAs of $E$. coli described by Duguid et al. (1979) had a spectrum of haemagglutinating activity like those of salmonellae.

In their excellent electronmicroscopical study of the colonisation factors present on bovine, enterotoxigenic strains of $E$. coli, Duchet-Suchaux et al. (1988) reported that the structure of F41 colonisation factor was complex. Thus, although individual F41 filaments were thin and had a diameter of $c$. $3 \mathrm{~nm}$, they were more generally present as thick, coil-like structures consisting of two or more filaments tightly wound on themselves to form dense spirals; again, large amounts of thick surface structures lay free in the medium. F41, therefore, had an appearance not unlike that of the thick fimbriae of Sendai (see figs. 1-4, Duchet-Suchaux et al., 1988) and their subunit $\mathrm{M}_{\mathrm{r}} \mathrm{s}(29.5 \mathrm{Kda}$ for F41, de Graaf and Roorda, 1982) were also similar. But F41 coils were much thicker $(17-20 \mathrm{~nm})$ than
Sendai fimbriae and their associated MRHAs were different (Morris et al., 1982; Duchet-Suchaux et al., 1988). Furthermore, the finding that all three Sendai strains formed thin filaments, whereas thick fimbriae were formed by $\mathrm{MREHA}^{+}$strains only, led us to conclude that Sendai thick fimbriae were neither related to F41 nor formed similarly.

The presence of type- 1 fimbriae in salmonellae is associated not only with mannose-sensitive adhesive properties but also with the ability to form a type-1 fimbrial pellicle at the surface of liquid media incubated statically in air (Old and Duguid, $1970,1971)$; pellicle formation by type-1 fimbriate salmonellae is also mannose-sensitive (Old et al., 1968). It was interesting, therefore, to find that type-1 non-fimbriate Sendai strains also formed fimbrial pellicles in liquid media but by a process that was mannose insensitive and restricted to $\mathrm{MREHA}^{+}$strains of Sendai. Although pellicle formation by type-1 fimbriate salmonellae and $\mathrm{MREHA}^{+}$fimbriate Sendai is associated in vitro with the attainment of growth yields greater than those achieved by non-fimbriate or MREHA $^{-}$ cultures, it is not clear what, if any, function this property fulfils in vivo. The demonstration in this study and elsewhere (Duguid et al., 1966) that adherence by Sendai strains to a wide range of substrates is MREHA-dependent suggests that the thick fimbriae may contribute to the overall adhesiveness of Sendai strains; however, the finding that this fimbrial MREHA is not produced by all naturally occurring Sendai strains makes it unlikely that it is an essential virulence determinant.

Most of the salmonellae recovered from human infections belong to subspecies 1 (Le Minor, 1988) and to prototrophic, ubiquitous serotypes which inhabit a wide range of hosts; in man, they usually 
cause a mild gastroenteritis. A few salmonellae, however, belong to serotypes-such as Paratyphi A and Typhi-which are auxotrophic and hostadapted to man in whom they cause systemic disease. Among salmonellae of group O9, two serotypes of subspecies 1 have the antigenic formula 1,9,12:a:1,5, namely, Sendai and Miami (Le Minor and Popoff, 1988). Sendai, first isolated from cases of enteric fever in Japan (Aoki and Sakai, 1925), is another, albeit less-well known, example of a serotype adapted to man and its biochemical properties are remarkably similar to those of Paratyphi A (1,2,12:a:[1,5]) (Ewing, 1985); there are, however, few reports of its isolation in Japan, or elsewhere, in recent years (Professor L. Le Minor, personal communication). Miami, by contrast, is a prototrophic, ubiquitous serotype causing a mild gastroenteritis in man; it too is infrequently recovered, e.g., only 13 isolations of Miami among 67767 strains of salmonellae in France in 1980-83 (Le Minor et al., 1985). Because strains of Sendai and Miami can be differentiated by biochemical properties only, the question has been raised as to whether both serotype names should be retained in the Kauffmann-White scheme (Le Minor and Popoff, 1988). However, this study has established that Miami strains, like most other salmonellae, produce type-1 fimbriae but never MREHAassociated fimbriae whereas Sendai strains, even if they produce MREHA, are never type-1 fimbriate.

\section{REFERENCES}

Adegbola R A, Old D C 1982 New fimbrial hemagglutinin in Serratia species. Infection and Immunity 38: 306-315.

Adegbola R A, Old D C, Aleksić S 1983 Rare MR/K-like haemagglutinins (and type 3-like fimbriae) of Salmonella strains. FEMS Microbiology Letters 19: 233-238.

Aleksić S, Rohde R, Aleksić V 1978 Serologische Verwandtschaft der Fimbrienantigene bei Salmonella Subgenus IYersinia enterocolitica einerseits und Salmonella Subgenus II-Arizona (=Salmonella Subgenus III) andererseits. Zentralblatt für Bakteriologie, Parasitenkunde, Infektionskrankheiten und Hygiene I, Originale A 241 : 418-426

Aoki K, Sakai K 1925 Ueber von Hogcholerabazillen einerseits, von Paratyphus A-Bazillen andererseits schwer differenzierbare, in Japan vorkommende Paratyphusbazillen. Centralblatt für Bakteriologie, Parasitenkunde und Infektionskrankheiten I, Originale A 95: 152-157.

Burke D A, Axon A T R 1987 Ulcerative colitis and Escherichia coli with adhesive properties. Journal of Clinical Pathology 40: $782-786$

de Graaf F K, Roorda I 1982 Production, purification and characterization of the fimbrial adhesive antigen F41 isolated from calf enteropathogenic Escherichia coli strain B41 M. Infection and Immunity 36: 751-758.

Duchet-Suchaux M, Bertin A, Dubray G 1988 Morphological description of surface structures on strain B41 of bovine
Thus, these two serotypes can be readily differentiated, albeit by fimbrial antigens which are not customarily considered when designating the antigenic formulae of Salmonella serotypes. Accordingly, the proposal to remove serotype Miami from the Kauffmann-White scheme because it is a biotype variant of Sendai would seem premature.

In the course of identifying the MREHA of Sendai strains as fimbrial, additional problems have been raised by this study. Thus, all three strains of Sendai produced thin filamentous structuresperhaps even two kinds - which, though not associated with adherence to epithelial cells, may have contributed to the high hydrophobicity of these strains. Despite many attempts, we were unsuccessful in detecting bands on gels of the column-purified fibrillar structures seen by electronmicroscopy. We can only assume that, because of the highly hydrophobic nature of the molecule, significant amounts were lost during the procedures of purification, dialysis and PAGE analysis. Although we know that other salmonellae host-adapted to man or other animals do not form MREHA (Duguid $e t$ al., 1966), we have no information about how widely distributed these filamentous structures are in host-adapted or ubiquitous serotypes of Salmonella.

We thank Professor L. Le Minor for the gift of strains and information about them. D.E.Y. thanks the CVCP(UK) for an Overseas Research Student Award. enterotoxigenic Escherichia coli bearing both K99 and F41 antigens. Journal of General Microbiology 134: 983-995.

Duguid J P 1985 Antigens of type-1 fimbriae. In: Stewart-Tull D E S, Davies M (eds) Immunology of the bacterial cell envelope. Wiley, Chichester, pp 301-318

Duguid J P, Campbell I 1969 Antigens of the type-1 fimbriae of salmonellae and other enterobacteria. Journal of Medical Microbiology 2: 535-553.

Duguid J P, Old D C 1980 Adhesive properties of Enterobacteriaceae. In : Beachey E H (ed) Bacterial adherence (Receptors and recognition, series $B$, vol. 6). Chapman and Hall, London, pp 185-217.

Duguid J P, Anderson E S, Campbell I 1966 Fimbriae and adhesive properties in salmonellae. Journal of Pathology and Bacteriology 92 : 107-138.

Duguid J P, Clegg S, Wilson M I 1979 The fimbrial and nonfimbrial haemagglutinins of Escherichia coli. Journal of Medical Microbiology 12: 213-227.

Duguid J P, Smith I W, Dempster G, Edmunds P N 1955 Nonflagellar filamentous appendages ("fimbriae") and haemagglutinating activity in Bacterium coli. Journal of Pathology and Bacteriology 70: 335-348.

Ewing W H 1985 Edwards and Ewing's Identification of Enterobacteriaceae, 4th edn. Elsevier, New York.

Firon N, Ofek I, Sharon N 1983 Carbohydrate specificity of the surface lectins of Escherichia coli, Klebsiella pneumoniae and 
Salmonella typhimurium. Carbohydrate Research 120: 235249.

Halula M C, Stocker B A D 1987 Distribution and properties of the mannose-resistant hemagglutinin produced by Salmonella species. Microbial Pathogenesis 3: 455-459.

Jones G W, Richardson L A 1981 The attachment to, and invasion of, HeLa cells by Salmonella typhimurium: the contribution of mannose-sensitive and mannose-resistant haemagglutinating activities. Journal of General Microbiology 127: 361-370.

Korhonen T K, Lounatmaa K, Ranta, H, Kuusi N 1980 Characterization of type-1 pili of Salmonella typhimurium LT2. Journal of Bacteriology 144: 800-805.

Laemmli U K 1970 Cleavage of structural proteins during the assembly of the head of bacteriophage T4. Nature 227: 680685.

Le Minor L 1988 Typing of Salmonella species. European Journal of Clinical Microbiology and Infectious Diseases 7: 214-218.

Le Minor L, Popoff M Y 1987 Designation of Salmonella enterica sp. nov., nom. rev., as the type and only species of the genus Salmonella. International Journal of Systematic Bacteriology 37: 465-468.

Le Minor L, Popoff M Y 1988 Antigenic formulas of the Salmonella serovars, 5th revision. WHO Collaborating Centre for Reference and Research on Salmonella, Institut Pasteur, Paris, France.

Le Minor L, Le Minor S, Grimont P A D 1985 Rapport quadriennal du Centre national des Salmonella sur l'origine et la répartition en sérotypes des souches isolées en France continentale au cours des anées 1980 à 1983. Revue $d$, Epidemiologie et de Sante Publique 33: 13-21.

Lindquist B L, Lebenthal E, Lee P-C, Stinson M W, Merrick J M 1987 Adherence of Salmonella typhimurium to smallintestinal enterocytes of the rat. Infection and Immunity 55: 3044-3050.

MacNab R M 1987 Flagella. In: Neidhardt F C (ed) Escherichia coli and Salmonella typhimurium Cellular and Molecular Biology, vol. 1. American Society for Microbiology, Washington D.C., pp 70-83.

Manning E J, Baird G D, Jones P W 1986 The role of plasmid genes in the pathogenicity of Salmonella dublin. Journal of Medical Microbiology 21 : 239-243.

Morris J A, Thorns C, Scott A C, Sojka W J, Wells G A 1982 Adhesion in vitro and in vivo associated with an adhesive antigen (F41) produced by a K99 mutant of the reference strain Escherichia coli B41. Infection and Immunity 36: 11461153.

Old D C 1972 Inhibition of the interaction between fimbrial haemagglutinins and erythrocytes by D-mannose and other carbohydrates. Journal of General Microbiology 71: 149 157.
Old D C 1985 Haemagglutination methods in the study of Escherichia coli. In: Sussman M (ed) The virulence of Escherichia coli: reviews and methods. Academic Press, London, pp 287-313.

Old D C, Adegbola R A 1985 Antigenic relationships among type-3 fimbriae of Enterobacteriaceae revealed by immunoelectronmicroscopy. Journal of Medical Microbiology 20: 113-121.

Old D C, Duguid J P 1970 Selective outgrowth of fimbriate bacteria in static liquid medium. Journal of Bacteriology 103: $447-456$.

Old D C, Duguid J P 1971 Selection of fimbriate transductants of Salmonella typhimurium dependent on motility. Journal of Bacteriology 107: 655-658.

Old D C, Tavendale A 1986 Adhesion of Salmonella dublin to HEp2 epithelial cells. Letters in Applied Microbiology 3: 7376.

Old D C, Corneil I, Gibson L F, Thomson A D, Duguid J P 1968 Fimbriation, pellicle formation and the amount of growth of salmonellas in broth. Journal of General Microbiology $51: 1-16$.

Old D C, Klaassen B, Crichton P B 1985 A novel, non-fimbrial mannose-sensitive and eluting (MSE) haemagglutinin of Yersinia frederiksenii strains. FEMS Microbiology Letters 28: $81-84$.

Old D C, Yakubu D E, Crichton P B 1987 Demonstration by immuno-electronmicroscopy of antigenic heterogeneity among $\mathrm{P}$ fimbriae of strains of Escherichia coli. Journal of Medical Microbiology 23 : 247-253.

Rohde R, Aleksić S, Müller G, Plavsić S, Aleksić V 1975 Profuse fimbriae conferring $\mathrm{O}$-inagglutinability to several strains of $S$. typhimurium and $S$. enteritidis isolated from pasta products. Cultural, morphological and serological experiments. Zentralblatt für Bakteriologie, Parasitenkunde, Infektionskrankheiten und Hygiene I, Originale A 230 : 38-50.

Rozgonyi F, Szitha, K R, Ljungh $\AA$, Baloda S B, Hjertén S, Wadström $T 1985$ Improvement of the salt aggregation test to study bacterial cell-surface hydrophobicity. FEMS Microbiology Letters 30: 131-138.

Sato H, Okinaga K 1987 Role of pili in the adherence of Pseudomonas aeruginosa to mouse epidermal cells. Infection and Immunity 55: 1774-1778.

Scott S S, Old D C 1981 Mannose-resistant and eluting (MRE) haemagglutinins, fimbriae and surface structure in strains of Haemophilus. FEMS Microbiology Letters 10: 235-240.

Tavendale A, Jardine C K H, Old D C, Duguid J P 1983 Haemagglutinins and adhesion of Salmonella typhimurium to HEp2 and HeLa cells. Journal of Medical Microbiology 16: $371-380$

Yakubu D E, Senior B W, Old D C 1989 A novel fimbrial haemagglutinin produced by a strain of Salmonella of serotype Salinatis. FEMS Microbiology Letters 57: 29-34. 